Leading by example, saving energy and taxpayer dollars in federal facilities

\section{$\frac{5}{1 \%}$}

\section{Energy Efficiency}

and Renewable Energy

Bringing you a prosperous future where energy is clean, abundant, reliable, and affordable

Natural Gas Supplies and Prices: September 2005

\title{
FEMP Energy Savings Expert Teams to Help Federal Facilities Immediately Reduce Demand and Consumption
}

\section{Status of the U.S. Natural Gas Supply}

Demand for natural gas in the United States has risen steadily over the past decade, fueled in part by increased consumption of natural gas for electricity generation. At the same time, domestic production has declined since its peak in the mid-1970s, and recent efforts to encourage drilling activity have had limited results. Hurricanes Katrina and Rita led to natural gas being "shut in," which has contributed to dramatic price increases. Monthly average spot prices for natural gas supplies this coming winter are currently fluctuating around \$12-13 mmBtu-about twice the average last year.

Developing significant new supplies of natural gas will take time but, in the short term, reducing demand through energy conservation, efficiency, load management, and fuel switching can help hold down the price of natural gas. Actions taken now to improve efficiency and minimize consumption and dependence on natural gas will also be critical in buffering agency budgets from price volatility.

\section{FEMP ROLE and ESET Response}

FEMP, the Federal Energy Management Program, continues to lead in promoting the efficient use of energy resources through targeted energy conservation, efficiency, and load management at federal facilities. FEMP is offering energy savings expert teams (ESET) assessments (formerly called ALERT [Assessment of Load and Energy Reduction Techniques]) for federal facilities as part of a broad strategy to reduce natural gas consumption at these facilities.
An increase of $\$ 1 / \mathrm{mmBtu}$ in natural gas prices increases energy costs to the government by $\$ 111,000,000$. Containment of energy costs continues to be a high priority as agency budgets reflect the impact of international and Homeland Security efforts. ESET assessments will provide opportunities for federal facilities to significantly reduce energy use and to cut energy costs.

\section{ESET Assessments In FY 2006}

FEMP will assess 25 new sites during fiscal year 2006. The cost to FEMP per site assessment is expected to range between $\$ 15,000$ and $\$ 35,000$.

\section{From the Presidential Directive,} September 26, 2005

Therefore, I hereby direct the heads of executive departments and agencies to take appropriate actions to conserve energy use at their facilities to the maximum extent consistent with the effective discharge of public responsibilities. Federal facilities in regions where natural gas shortages are possible should conserve especially during periods of peak consumption. Also, Federal facilities in regions dependant on natural gas for generation of electricity should take action to conserve electricity. Furthermore, the actions should include the curtailment of discretionary travel, the acceleration of procurement of high efficiency or alternatively fueled vehicles, and the implementation of all other appropriate actions to reduce the use of natural gas and petroleum based fuels. 


\section{Criteria for Site Selection}

Working with agency personnel and the Department of Energy (DOE) Regional Offices, the following criteria will be used to identify potential ESET candidates:

- Active project champion and management support

- Resources to participate in the assessment and implement the recommendations

- Significant natural gas consumption at the site

- Significant potential savings (i.e., preference for large facilities and older systems)

- Utility bills paid by agency

- Ability to share costs. Cost-sharing contribution by the agency may be in the form of in-kind services, funding for a support contractor to participate in the ESET assessment, or support for FEMP ESET replication efforts by organizing and funding an agency ESET workshop to learn the techniques.

\section{ESET Assessment Procedure}

- Agencies submit request to DOE

- Sites are selected based on ESET screening criteria

- Two interviews before the site visit by ESET team: Initial interview and completion of an in-depth questionnaire on site buildings, equipment, and energy use

- Site visit includes kick-off meeting, brief site/ facility tour and measure targeting, investigation of targeted measures and possible implementation of select opportunities, follow-up discussion, and consensus on action items

- Draft report issued for rapid site review and written feedback

- Issuance of final report incorporating site feedback

- Site implements remaining recommendations

- Follow-up by DOE Regional Office to gather information on implementation status for FEMP's report.

\section{For More Information}

AB Ream

Federal Energy Management Program

U.S. Department of Energy, EE-2L

1000 Independence Ave., SW

Washington, DC 20585-0121

Phone: 202-586-7230

E-mail: ab.ream@hq.doe.gov
A Strong Energy Portfolio for a

Strong America

Energy efficiency and clean, renewable energy will mean a stronger economy, cleaner environment, and greater energy independence for America. Working with a wide array of state, community, industry, and university partners, the U.S. Department of Energy's Office of Energy Efficiency and Renewable Energy invests in a diverse portfolio of energy technologies.

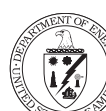
Energy Efficiency
and Renewable Energy

Bringing you a prosperous future where energy is clean, abundant, reliable, and affordable

Produced for the U.S. Department of Energy by the National Renewable Energy Laboratory, a DOE national laboratory

DOE/GO-102005-2234

October 2005 